\title{
FANCC Gene Amplification
}

National Cancer Institute

\section{Source}

National Cancer Institute. FANCC Gene Amplification. NCI Thesaurus. Code C131456.

A molecular genetic abnormality indicating the presence of multiple copies of the FANCC gene. 